\author{
Anna DUDA \\ Uniwersytet Jagielloński \\ anna.duda@doctoral.uj.edu.pl
}

\title{
CZARNOBYL W STREFIE POSTPAMIĘCI
}

\author{
O NARRACJI PRZEWODNICKIEJ \\ ALEKSANDRA SIROTY - „MERA” PRYPECI
}

ABSTRACT Chernobyl in the Postmemory Zone. The Guide Narration of Alexander Sirota - ,the Mayor" of Pripyat

The goal of this article is to show how the memory of Chernobyl catastrophe is being reconstructed and later pass on by the guide with his narration. The example of Aleksander Sirota and his mother will show how big of a factor in constructing memory of a 'second generation' is played by post-traumatic creation of a close person, as well as accumulated video recordings and photographies taken before the accident. Also, comperative approach of confronting photos with authentic 'forgotten' space of Pripyat city used by the tour guide will allow us to understand the level of influence in which visual aspect can affect reinterpretation of abandoned heritage. The same can be said of actual presence of a tourist in such environment and its effect on alteration of the memory of the event. The activity of Aleksander Sirota presented in this article will allow us to look at Chernobyl catastrophe through the lens of post-memory discourse and will reveal how multilayered research issue it really is.

Keywords: Chernobyl Exclusive Zone (CEZ), Pripyat, postmemory, tourism of difficult heritage

Slowa kluczowe: Czarnobylska Strefa Wykluczenia (CSW), Prypeć, postpamięć, turystyka trudnego dziedzictwa 
W szkole nudzitem się, nic mnie tam nie interesowato. Nieraz marzytem, żeby rozpadta się w gruzy. Dlatego uważaj, o czym marzysz, bo może się spetnić.

Aleksander Sirota $^{1}$

W 1986 roku Czarnobyl ${ }^{2}$ stał się czarnym punktem na mapie świata. Miejsce to od momentu awarii elektrowni jądrowej wzbudzało strach, napięcie, niepokój. W całej Europie (przede wszystkim jednak na Ukrainie i Białorusi oraz w państwach ościennych) pojawiały się pytania: czy Czarnobyl naprawdę dotyczy również mnie? Czy ma wpływ akurat na moje życie? Jeżeli tak, to jak uchronić się przed działaniem czynników radioaktywnych? Komu mogę zaufać? Kto udzieli mi rzetelnych informacji na temat skutków katastrofy? „Niewidzialny wróg” siał terror, obudowując się jednocześnie narracją, w którą nawet dziś - 30 lat po awarii - trudno ingerować. Obraz poczarnobylskiej rzeczywistości nie został zdeterminowany przez wiarygodne statystyki, które mówią, że skutki wybuchu były dużo mniejsze, niż przypuszczano początkowo. Nie pomagają również wypowiedzi takich autorytetów jak prof. Zbigniew Jaworowski ${ }^{3}$ czy komentarze współczesnych fizyków jądrowych. Obraz czarnobylskiej przestrzeni w oczach młodego pokolenia ukształtowany został przez wyobrażenia i wspomnienia osób, które dobrze zapamiętały uczucie paniki oraz brak zaufania wobec radzieckich władz, długo ukrywających czarnobylską prawdę. Oprócz wciąż żywej pamięci świadków wydarzeń myślenie o Czarnobylu zdeterminowała również kultura popularna

$1 \quad$ M. Wyrwał, Po katastrofie w Czarnobylu wyjechat na cate życie. Powrót jest bolesny, [online] http://wiadomosci.onet.pl/tylko-w-onecie/po-katastrofie-w-czarnobylu-wyjechal-na-cale-zycie-powrot-jest-bolesny/t0lzxs, 24 VIII 2016.

226 kwietnia 1986 roku o godz. 1.23 doszło do katastrofy w elektrowni jądrowej w Czarnobylu. Wybuch był wynikiem eksperymentu, który doprowadził do przegrzania reaktora, a następnie eksplozji wodoru oraz pożaru. Za sprawą awarii doszło do uwolnienia się substancji promieniotwórczych. Największe skażenie można było zarejestrować na pograniczu Białorusi, Ukrainy i Rosji, radioaktywna chmura zaś rozprzestrzeniła się po całej Europie. Po przesiedleniu ok. 350 tys. mieszkańców wyznaczono strefę, do której wstęp do niedawna mieli tylko nieliczni.

3 Zbigniew Jaworowski, nieżyjący już ekspert ds. wpływu promieniowania na zdrowie człowieka, wieloletni kierownik Zakładu Higieny Radiacyjnej w Centralnym Laboratorium Ochrony Radiacyjnej w Warszawie, członek grup doradczych Międzynarodowej Agencji Energii Atomowej, a w 1986 roku członek Polskiej Komisji Rządowej ds. Skutków Katastrofy Czarnobylskiej. To właśnie on zalecił wówczas podanie mieszkańcom Polski, głównie dzieciom, płynu Lugola - wodnego roztworu czystego, nieradioaktywnego jodu w jodku potasu. W artykule pt. Czarnobyl napisał: Zniszczenie reaktora $w$ Czarnobylu byto największa katastrofa psychologiczna w czasie pokoju. [...] Natomiast z punktu widzenia rzeczywistych strat ludzkich (31 zgonów wśród pracowników i ratowników napromienionych wielkimi jednorazowymi dawkami od 800 do $16000 \mathrm{mSv}$, w tym 3 zgony od oparzeń $i$ urazów mechanicznych) byta to niewielka katastrofa przemystowa. [...] Zamiast masowych zgonów radiacyjnych po Czarnobylu wystapita epidemia chorób psychosomatycznych (choroby serca, przewodu pokarmowego, psychiczne itp.), nie mających nic wspólnego z promieniowaniem, a wywotanych stresem po katastrofie, btędami wtadz, oraz sztucznym stworzeniem masowego syndromu 5 milionów „ofiar Czarnobyla”, tj. lu$d z i$ żyjacych na tzw. silnie skażonych terenach i otrzymujacych za to statą rekompensatę pieniężna. Z. Jaworowski, Czarnobyl, „Racjonalista” 2009, 10 IV, [online] http://www.racjonalista.pl/kk.php/s, 31 VIII 2016. 
odnosząca się w grach komputerowych ${ }^{4}$, muzyce ${ }^{5}$, literaturze ${ }^{6}$, filmie ${ }^{7}$, fotografii ${ }^{8}$ do postapokaliptycznych wizji Czarnobylskiej Strefy Wykluczenia (CSW).

Konsekwencją różnic w myśleniu o Czarnobylu jest chęć wyjazdu' do CSW, najczęściej osób młodych, które w pewien sposób utożsamiają się z katastrofą. Jest to pokolenie trzydziestolatków określających się często jako „dzieci Czarnobyla” ${ }^{10}$, czyli osoby urodzone w 1986 roku oraz krótko przed katastrofą. Jeszcze inny profil „turysty” zarysowuje się w przypadku osób 20+, których spojrzenie na Czarnobyl w dużo większym stopniu ukształtowały obrazy kultury popularnej. Jednocześnie oprócz osób, które chcą doświadczyć grozy opuszczonego miejsca, na horyzoncie pojawiają się ci, którzy turystom chcą opowiedzieć o rodzinnym dramacie i traumie ${ }^{11}$, w cieniu której żyli lub się wychowywali. Ukraińskie biura turystyczne, organizujące wycieczki do Czarnobyla, zakładane są przez osoby bezpośrednio związane z katastrofą lub przez ich dzieci. Misyjny $^{12}$ charakter działalności podkreślany jest przez większość przewodników.

4 Gry komputerowe Call of Duty IV oraz S.T.A.L.K.E.R., których akcja rozgrywa się w Czarnobylskiej Strefie Wykluczenia, a także Fallout, przedstawiający świat postapokaliptycznej Ameryki.

5 Za przykład może tu posłużyć utwór Kraftwerka Radioactivity z 1975 roku, który twórcy przerobili w 1991 roku, nawiązując wprost do Czarnobyla i innych miejsc bezpośrednio kojarzących się z niszczycielską siłą atomu.

6 O Czarnobylu pisała m.in. Swietlana Aleksijewicz, która w książce pt. Czarnobylska modlitwa. Kronika przysztości (przeł. J. Czech, Wołowiec 2012, Reportaż - Wydawnictwo Czarne) opowiada historie osób bezpośrednio związanych z katastrofą. Znany jest również reportaż Francesca M. Catalucciego Czarnobyl (przeł. P. Bravo, Wołowiec 2013, Sulina).

7 Czarnobyl. Reaktor strachu (oryg. Czernobyl Diaries), reż. B. Parker, 2012 oraz Szklana putapka 5 (oryg. A Good Day to Die Hard), reż. J. Moore, 2013.

8 Maciej Nabrdalik - zdobywca World Press Photo 2014; wielokrotnie fotografowal wysiedlone tereny Czarnobylskiej Strefy Wykluczenia, a jednocześnie uwagę swą skupił na tzw. samosiołach - osobach, które powróciły do Czarnobyla i do dzisiaj mieszkają w Zonie. Zob. Maciej Nabrdalik, [online] http://culture.pl/pl/tworca/maciek-nabrdalik\#dziela, 28 VIII 2016.

9 Mowa tu o wycieczkach turystycznych trwających nie dłużej niż kilka dni, z noclegiem w Kijowie lub Sławutyczu.

10 Stwierdzenie to wielokrotnie padało z ust polskich turystów podczas wycieczki do Czarnobyla (14-17 kwietnia 2016 r.; wyjazd z biurem turystycznym Bis-Pol).

11 Skala wydarzeń w Czarnobylu wywołała traumę zbiorową, która z czasem osiągnęła poziom traumy kulturowej, z tego względu, że pytania o odpowiedzialność za katastrofę przeniosły się na sferę publiczną. Ekatherina Zhukova czarnobylską traumę kulturową podzieliła na dwa okresy. Pierwszy - tzw. countinous trauma (trauma uobecniająca) obejmująca lata 1986-1991, czyli od momentu wybuchu do rozpadu Związku Radzieckiego i uzyskania przez Bialoruś i Ukrainę niepodległości. W tym czasie podejmowano próby odpowiedzi na pytania: Jakim społeczeństwem jesteśmy, skoro doszło do takiej tragedii? Kto jest za to odpowiedzialny? Drugi okres to tzw. retrospective trauma (trauma retrospektywna) trwająca od $1991 \mathrm{r}$. do chwili obecnej. Tu nastąpiła zmiana w myśleniu, podyktowana poczuciem większej tożsamości narodowej. Następuje próba odpowiedzi na pytania: Jakim społeczeństwem bylismy? Kto byt za to odpowiedzialny? Zob. E. Zhukova, From Ontological Security to Cultural Trauma: The Case of Chernobyl In Belarus and Ukraine, „Acta Sociologica” 2016, nr 59(4), s. 336-339.

12 Robert Lifton, psychiatra zajmujący się psychologicznymi skutkami traumy, przeprowadził w $1980 \mathrm{r}$. badania, w wyniku których m.in. stwierdza, że osoby, które przeżyły katastrofę lub wychowywały się w jej cieniu często odczuwały poczucie winy wobec ofiar i osób najbardziej poszkodowanych. Zadawały sobie pytanie: „Dlaczego ja przetrwałem, skoro inni umarli ?”. Odpowiedzią na to są podejmowane 
Patrząc na Czarnobyl przez pryzmat postpamięci ${ }^{13}$, z humanistycznego punktu widzenia zarysowuje się kilka perspektyw badawczych. Magdalena Saryusz-Wolska, w ramach studiów nad pamięcią, lokuje zaproponowany przez Marianne Hirsch termin $\mathrm{w}$ ramach ujęcia antropologicznego, podkreślając silny związek postpamięci z antropologią fotografii ${ }^{14}$. Przykład Aleksandra i Lubow Sirotów skłania do ujęcia problemu szerzej. Ich historia ukazuje, w jaki sposób pamięć o wydarzeniach jest konstruowana oraz jak świadectwo matki jest odbierane przez syna, a następnie transmitowane w formie narracji przewodnickiej przyjezdnym do CSW.

Wychodząc od analizy strony internetowej Pripyat.com ${ }^{15}$, założonej przez Aleksandra Sirotę, ukazana zostanie misja, cel oraz „spojrzenie” na czarnobylskiego turystę oczami człowieka naznaczongo wydarzeniami z kwietnia 1986 roku. Wywiad kierowany z Aleksandrem Sirotą, przeprowadzony drogą mailową, uzupełniony będzie ujęciem kulturoznawczym, polegającym na analizie treści tekstów autorstwa jego oraz Lubow Siroty. Twórczość matki oraz oparta na postrzępionej pamięci działalność Aleksandra stawiają uniwersalne pytania. Gdzie kończy się dokument, a zaczyna twórczość? W którym momencie kończą się wspomnienia, a zaczynają wyobrażenia? Czym różni się pamięć autentyczna od pamięci zapośredniczonej? Podjęta w niniejszym artykule refleksja oparta będzie nie tylko o teksty Marianne Hirsh, przywołane zostaną również inne nazwiska, które na stałe wpisały się do kanonu studiów nad pamięcią, tj. Pierre Nora, Paul Ricoeur, Reinhart Koselleck.

W 1980 roku Pierre Nora zwrócił uwagę na szerzącą się w społeczeństwach „obsesję pamięci”, wprowadzając jednocześnie na stałe do słownika akademickiego pojęcie lieux de memoire (miejsce pamięci) ${ }^{16}$. Czarnobyl w kontekście panującego dyskursu

działania na rzecz zachowania pamięci o tragicznych wydarzeniach, stąd osoby „ocalałe” często mówią poczuciu "misji” do spełnienia. A. Sawada, J. Chaitin, D. Bar-On, Surviving Hiroshima and Nagasaki - Experiences and Psychosocial Meanings, „Psychiatry” 2004, Vol. 67, nr 1, s. 46.

13 Termin „postpamięć” zaproponowała Marianne Hirsch, która pisze: $W$ moim rozumieniu, postpamięć od pamięci odróżnia pokoleniowy dystans, a od historii gtęboka osobista więź. Postpamięćjest silną i bardzo szczególna formą pamięci wtaśnie dlatego, że jej relacja wobec przedmiotu czy źródta jest zapośredniczona nie poprzez wspomnienia, ale wyobraźnię i twórczość. [...] Postpamię́c charakteryzuje doświadczenie tych, którzy dorastali w środowisku zdominowanym przez narracje wywodzace się sprzed ich narodzin. Ich wtasne spóźnione historie ulegają zniesieniu przez historie poprzedniego pokolenia uksztattowane przez doświadczenia traumatyczne, którego nie sposób ani zrozumié, ani przetworzyć. M. Hirsch, Żatoba i postpamięć, [w:] Teoria wiedzy o przesztości na tle wspótczesnej humanistyki. Antologia, red. E. Domańska, Poznań 2010, s. 254.

14 Magdalena Saryusz-Wolska pisze: W epoce „wędrujacych konceptów” (travelling concepts, Mieke Bal) trzeba podjacć jakaśs decyzję, by postulowana interdyscyplinarność nie zamieniata się w zwykty chaos. Wyróżnia kilka dominujących perspektyw w badaniach i teoriach pamięci zbiorowej: perspektywę społeczną, która obejmuje również ujęcie antropologiczne, perspektywę filozoficzno-historyczną oraz perspektywę kulturową. M. Saryusz-Wolska, Spotkania czasu z miejscem. Studia o pamięci i miastach, Warszawa 2011, s. 22-42, Communicare.

15 http://www.pripyat.com, 1 IX 2016.

16 P. Nora, Między pamięcia a historią. Les lieux de mémoire, przeł. W. Dłuski, „Tytuł Roboczy: Archiwum" 2009, nr 2, s. 4-12, [online] http://www.marysialewandowska.com/wp-content/uploads/2009/08/Archiwum-no2-c2-sprd.pdf, 24 V 2017. 
tzw. chęci upamiętniania jest miejscem wyjątkowym. Przede wszystkim, ze względu na wysoką radioaktywność terenu, tuż po katastrofie wydzielono strefę zamkniętą, do której nie mieli wstępu nawet jej byli mieszkańcy. Z czasem miasto Prypeć ${ }^{17}$ stało się nie tyle miejscem porzuconym, ile zapomnianym. W Czarnobylu pojawiały się co prawda pomniki poświęcone ofiarom katastrofy, jednak zabrakło osób, które by je regularnie odwiedzały. Miejsce więc w pewnym sensie nie spełniało swej pierwotnej funkcji upamiętniania. Można wręcz pokusić się o stwierdzenie, że czarnobylskie miejsce pamięci było przez długi czas jednocześnie miejscem zapomnianym. Dosłowność sytuacji niejako prowokuje odwołanie się do mitologii greckiej, w której oblubienica Zeusa oraz matka muz to Mnemosyne - bogini pamięci. Córki jednak przyniosty ludziom również lesmosyne, zdolność zapominania o cierpieniu i ustanie trosk ${ }^{18}$. Trauma spowodowana tragedią lub katastrofą sprawia, że chęć zapomnienia jest w wielu przypadkach równie silna jak potrzeba pamięci. W kontekście postpamięci relacja tych dwóch pojęć jest szczególnie mocna ze względu na pragnienie odzyskania poszarpanej i niechcianej pamięci przez drugie pokolenie. Córką Pamięci jest więc Zapomnienie, której pragnieniem jest zbliżenie się do matki.

Budowanie żywego, wirtualnego pomnika pamięci przyświeca działalności Aleksandra Siroty, mieszkającego w pobliżu Czarnobyla, we wsi Ditjatki. Ze względu na jego wielkie zaangażowanie nazywany jest „merem” Prypeci. Pripyat.com - prowadzona przez niego strona internetowa - w pełni poświęcona jest miastu. W 2007 roku Center Pripyat.com została zarejestrowana jako organizacja pozarządowa walcząca m.in. z szabrownikami pustoszącymi CSW. Służy również jako wielka platforma komunikacyjna między wysiedleńcami rozproszonymi nie tyle po Ukrainie, ile po całym świecie. W ramach projektu Pripyat.com byli mieszkańcy stworzyli archiwum prypeckich zdjęć i wspomnień sprzed roku 1986 roku. Na stronie znajdują się również zakładki dotyczące literatury i sztuki, gdzie motywem przewodnim jest Czarnobylska Strefa Wykluczenia, a także informacje dotyczące Muzeum Czarnobyla oraz cenne archiwalne dokumenty dotyczące katastrofy i wydarzeń po 26 kwietnia 1986 roku. Oprócz wielkiej bazy wiedzy, jaką stanowi Pripyat.com, w ścisłym z nią związku działa biuro Cherobylstore.pl, organizujące wycieczki do CSW. Przewodnikiem często jest Aleksander Sirota, który stwierdza: Ludzie przyjeżdzaja tu z różnych powodów - jedni chca zobaczyć, jak mogtaby wygladać apokalipsa, inni chca poczuć historię. Dla jeszcze innych - jest to ich dzieciństwo i chca zobaczyć, jak zachowata się tu sowieck a atmosfera. Dla mnie jednak dużo ważniejsze jest nie to, dlaczego oni tu przyjeżdżaja, ale jakie to robi na nich wrażenie i jaki ma na nich wptyw ${ }^{19}$.

Pomimo pierwiastka edukacyjnego, który pojawia się w misji większości biur podróży, „turystyka” w Czarnobylu wywołuje liczne kontrowersje. Pierwszą z nich są

17 Miasto zostało założone w 1970 roku z myślą o pracownikach elektrowni jądrowej w Czarnobylu, oddalonej od Prypeci zaledwie trzy kilometry. 27 kwietnia 1986 rou wysiedlono ok. 50 tys. osób. Mieszkańcy nigdy nie powrócili do swych domów. Dziś Prypeć nazywana jest miastem widmem.

18 M. Saryusz-Wolska, Spotkania czasu z miejscem..., s. 70.

19 Chernobyl dead zone to close to tourists, [online] https://www.rt.com/news/chernobyl-tourist-no-go-zone-397, 29 VIII 2016. 
oczywiście wciąż powracające pytania o bezpieczeństwo w Zonie. O ile jednak tu specjalistyczne ośrodki badawcze mogą udzielić wiarygodnej i w miarę precyzyjnej odpowiedzi, o tyle dużo więcej rodzi się problemów natury etycznej. Pierwsze zastrzeżenia pojawiają się już na poziomie nomenklatury. Państwowa Agencja ds. Zarządzania Strefą Wykluczenia zwraca szczególną uwagę, by stosować termin „wizyta” (віАвіАування) i „odwiedzający” (відвідувачів), nie „turystyka” і „turyści”, zaś grupy nazywane są delegacjami (Аемегація), a nie grupami turystycznymi. Specjalna nomenklatura dostosowana jest do ukraińskiego prawa, które mówi, że na terenie strefy wykluczenia nie mogą być świadczone usługi turystyczne.

Mimo że na większości stron biur podróży można przeczytać hasła bezpośrednio odnoszące się do niezapomnianego doświadczenia turystycznego w Zonie, to problem nazewnictwa istnieje również w sferze języka potocznego. Terminu „turystyka” szczególnie unikają osoby bezpośrednio związane z katastrofą - wysiedleńcy chcący zobaczyć CSW po trzydziestu latach, przewodnicy czy też badacze lub dziennikarze, którzy przyjeżdżają najczęściej w innych celach niż turystyczne ${ }^{20}$. Aleksander Sirota również zwraca uwagę na wyjątkowość wyjazdów co CSW, mówiąc: Nie jesteśmy biurem turystycznym, ale grupa doświadczonych eksplorerów, którzy przez prawie dziesięć lat pracują w Zonie. Wszystkie wyprawy odbywaja dzięki pozwoleniu Departamentu ds. Strefy Wykluczenia. Pomimo, że używamy stowa "wycieczka” - oczywistego dla ogótu spoteczeństwa, to dużo bardziej wtaściwe bytoby postugiwanie się terminami: "eksploracja” " „wyprawa” 21 .

Opisane powyżej kontrowersje sytuują Czarnobyl w orbicie pojęcia „trudnego dziedzictwa" (difficult heritage ${ }^{22}$, dissonant heritage ${ }^{23}$ ). Jak piszą Sabina Owsianowska i Magdalena Banaszkiewicz: [trudne dziedzictwo] jest to spadek, z którym dobrowolnie nikt nie chce sie identyfikować, ale który narzuca na żyjacych niezbywalny obowiazek uobecniania go $w$ teraźniejszości i zachowywania na przysztośćc ${ }^{24}$. Obawa przed stworzeniem w Czarnobylu „parku rozrywki” powoduje różnego rodzaju dysonanse, które widoczne są już na poziomie nomenklatury. Określenie „Czarnobyl jako atrakcja turystyczna” budzi liczne kontrowersje. Biorąc jednak pod uwagę sposób organizacji wycieczek, wyznaczanie specjalnych tras dla zwiedzających czy wydzielenie punktów widokowych, można mieć wszelkie podstawy, by miejsce to wpisać w obszar turystyki trudnego dziedzictwa ${ }^{25}$. Ponadto bardzo zły stan prypeckich budynków, groźba

20 Do CEZ najłatwiej dostać się jako „turysta” zorganizowanej wycieczki. Aby wjechać do CSW, wciąż wymagane jest specjalne pozwolenie Państwowej Agencji ds. Zarządzania Strefą Wykluczenia. W przypadku wycieczek wszelkimi formalnościami zajmują się biura podróży.

21 Pripyat.com, [online] http://www.pripyat.com, 1 IX 2016.

22 Zob. S. Macdonald, Difficult Heritage. Negotiating the Nazi Past in Nuremberg and Beyond, London 2009.

23 Zob. J.E. Tunbridge, G.J. Ashworth, Dissonant Heritage. The Management of the Past as a Resource in Conflict, Chichester 1996.

24 S. Owsianowska, M. Banaszkiewicz, Trudne dziedzictwo a turystyka. O dysonansie dziedzictwa kulturowego, „Turystyka Kulturowa” 2015, nr 11, s. 13.

25 W antropologii turystyki popularnymi pojęciami na określenie podróży do miejsc związanych ze śmiercią są „mroczna turystyka” oraz „tanatoturystyka”. Definicje te jednak swym zasięgiem obejmują 
zawalenia, a następnie ostatecznego „porzucenia” powoduje, że to właśnie turystyka może być pretekstem, aby rozpocząć działania renowacyjne w CSW, co jest priorytetem wielu czarnobylskich przewodników.

Działalność Aleksandra Siroty ukazuje, jak bardzo pamięć koresponduje z przyszłością. Paul Ricoeur wprost pisze, że nie ma takiej pamięci, która nie bytaby projektem ${ }^{26}$. Słowa te niewątpliwie znajdują odzwierciedlenie w postaci narracji przewodnickich. Są to opowieści oparte na wiedzy oraz własnych wspomnieniach, które jednak zawsze idą w parze z wyobrażeniami. Tworzone projekcje można w metaforyczny sposób odnieść do Reinharta Kosellecka dwóch kategorii, opisujących specyfikę pamięci: „przestrzeni doświadczenia” oraz „horyzontu oczekiwan'”27. By zrozumieć narrację Aleksandra Siroty, zawieszoną między przeszłością a przyszłością, warto tę opowieść zacząć po prostu od początku.

W 1995 roku Aleksander Sirota jako dziewiętnastolatek napisał list I want them to remember. A letter from a child of Chernobyl, który otwiera następującymi słowami: Wspomnienia... strzępy pamięci. To wszystko, co pozostato z niegdyśpięknego miasta Prypeć, które byto - choćnie na dtugo - moim domem ${ }^{28}$. W momencie katastrofy Sirota miał 10 lat. Był wówczas uczniem trzeciej klasy Miejskiej Szkoły Podstawowej nr 1. Marny byt ze mnie uczeń. W szkole nudzitem się. Nic mnie tam nie interesowato. Nieraz marzytem, żeby szkota rozpadta się w gruzy, dlatego uważaj o czym marzysz bo może się spetnić. [...] Miatem dobrego przyjaciela, z tej samej klasy. 26 kwietnia wracalismy ze szkoty do domu, w mieście rozeszta się plotka, że cośstato się $w$ elektrowni. Poszliśmy więc na most za miastem

nie tylko miejsca pamięci, egzekucji czy obozy zagłady, ale także „domy strachu”, nowoczesne muzea, np. Muzeum Titanica w Belfaście, czy parki rozrywki inscenizujące śmierć. Szerokie spektrum tzw. „mrocznych miejsc” wywołuje krytykę terminu i stawia wiele pytań natury etycznej. Przyczynia się do pejoratywnego odbioru „mrocznego turysty” przez osoby emocjonalnie związane z miejscem upamiętniającym tragedię. Zastosowany natomiast termin „turystyki trudnego dziedzictwa” podkreśla pojawiający się na wielu płaszczyznach dysonans, co nie tyle neguje zjawisko, ile otwiera dyskusję. Zob. M. Banaszkiewicz, Tanatoturystyka. Doświadczenie, pamięć, etyka, „Politeja” 2015, nr 3, s. 91-104.

P. Ricoeur, Pamięć - zapomnienie - historia, [w:] Tożsamość w czasach zmiany. Rozmowy w Castel Gandolfo, red. K. Michalski, Kraków 1995, s. 34, Demokracja - Znak.

27 Reinhart Koselleck pisze: W medium określonych doświadczeń i określonych oczekiwań realizuja się konkretne dzieje [...] doświadczenie jest wspótczesna przesztościa, której wydarzenia interioryzowane i które można sobie przypominać. [...] Następnie w każdorazowo wtasnym doświadczeniu zawiera się $i$ znosi zawsze obce doświadczenie, przekazywane przez pokolenia czy instytucje. W tym sensie historię z dawien dawna pojmowano jako wiedze o cudzym doświadczeniu. Podobnie określić można oczekiwanie: także ono związane jest z osobą, a jednocześnie z czymś międzyosobowym; także oczekiwanie realizuje się $w$ dniu dzisiejszym, jest uwspótczésniona przysztościa, odnosi się do „jeszcze nie”, do tego, co jeszcze nie stato się udziatem doświadczenia, do tego, co można jedynie przewidzieć. R. Koselleck, „Przestrzeń doświadczenia" i, "horyzont oczekiwań" - dwie kategorie historyczne, [w:] tegoż, Semantyka historyczna, oprac. H. Orłowski, Poznań 2012, s. 362-363.

28 A. Sirota, I want them to remember. A letter from a child of Chernobyl, „DHA News” 1995, nr 16, s. 24-25. 
bo stamtad byto ja widać. Tam spotkaliśmy wiele innych dzieciaków, ale nie zobaczyliśmy nic szczególnego więc wróciliśmy do miasta oglądać helikoptery, którymi już lądowato woj$s k o^{29}$. Aleksander w swym liście wspomina, jak w dzieciństwie często z kolegami bawili się w żołnierzy, jakby uczestniczyli w grze wojennej. Na drugi dzień po wybuchu zabawa miała szczególnie realistyczne tło. Helikoptery przelatywały nisko nad dachami domów, a po mieście chodzili żołnierze w maskach gazowych. Autobusy ustawione w rzędzie miały wywieźć mieszkańców z miasta "na trzy dni”30. Towarzysze czasowo opuszczajacy swoje mieszkania, nie zapomnijcie, prosze, zamknać okna, wytaczyć urzadzenia elektryczne i gazowe, zamknać zawory. Prosimy zachować spokój i porzadek podczas tymczasowej ewakuacji...” - mówił głos ze wszystkich głośników w mieście Prypeć (27 kwietnia 1986 roku, 36 godzin po wybuchu w elektrowni atomowej w Czarnobylu) ${ }^{31}$. Podczas wyjazdu z Prypeci chłopcy nadal bawili się zabawkowymi żołnierzykami, zupełnie nie zdając sobie sprawy, że zaczyna się nowy rozdziat wich życiu, ich krewnych i przyjaciót ${ }^{32}$. Aleksander wspomina, że dopiero w kilka miesięcy później, gdy niektóre dzieci wciąż czekały na rodziców i zastanawiały się, czy żyją, i gdy mówiono, że prawdopodobnie już nigdy nie powrócą do Prypeci, zrozumiał, że utracił wszystko to, co było mu najbliższe ${ }^{33}$ : Mogtem tylko marzyćo swoim mieście. Marzytem dtugo - do momentu pierwszej wycieczki do Zony. Wiosna 1994 r. uświadomitem sobie, że powrót jest niemożliwy ${ }^{34}$.

Dzień po wybuchu inaczej zapamiętała matka Aleksandra Siroty - Lubow Sirota, która miała wówczas blisko 30 lat. Tak wspomina moment katastrofy: $W$ nocy $z$ elektrowni dobiegt huk, a potem wybuch. Nie mogtam tej nocy spać, dtugo siedziatam przy oknie. Ale w naszym mieście czessto dochodzito do różnych wybuchów, więc nie zwracatam więszej uwagi. Rano wystatam syna do szkoty, a sama posztam do grupy literackiej. Rankiem 26 kwietnia w mieście dziwito tylko jedno - duża liczba samochodów polewających ulice. Pomyślatam, że miasto przygotowuje się do obchodów majowych. I w ogóle czutam się tak lekko, jakbym leciata nad ziemią. [...] Tylko potem analizowatam tę przypadtość. Taki efekt daje bardzo silne promieniowanie tta. U pracowników elektrowni jądrowych jest taki termin, który opisuje to uczucie - „kac jądrowy”35. Aleksander Sirota w internetowym wywiadzie kierowanym, zapytany o to, na ile jego wspomnienia korespondują ze wspomnieniami jego matki, odpowiada: Mamy różne wspomnienia o tych wydarzeniach. Oczywiście sa one ze soba związane w tych momentach, które przeżywaliśmy razem. Zazwyczaj opowiadam tylko to, co sam przeżytem, pamiętam bardzo dobrze to, czego bytem świadkiem. Mama jednak też nigdy mi nie pozwolita zapomnieć... to fakt. [...] Opowiadata o tym, co sie wydarzyto, jednak nie tyle mi, ile światu. A robita to poprzez swoja.

29 M. Wyrwat, Po katastrofie...

30 A. Sirota, I want them to remember...

31 Бегство от радиачии. Как семья, переживщая эвакуацию, хранит историю Припяти и спасает редких ломадец̆, [online] http://news.tut.by/society/486540.html, 24 VIII 2016.

32 A. Sirota, I want them to remember...

33 Tamże.

34 Tamże.

35 Бегство от радиации... 
wczesna poczarnobylska poezję, prace spoteczna, film Próg, scenariusz filmowy, który następnie ukazat się w postaci książki pt. Prypecki syndrom. Ja po prostu bytem w pobliżü.

Istniejący w twórczości Lubow Siroty wątek czarnobylski ukazuje sposób radzenia sobie z traumą poprzez dzielenie się swoimi przeżyciami z innymi. Jednocześnie jednak poezja oraz opowiadania matki wpływają na sposób przeżywania minionych wydarzeń przez syna. Swoje więc dziecięce spojrzenie na katastrofę Aleksander na przestrzeni lat konfrontował z doświadczeniem osoby dorosłej. Analizując wspomnienia Aleksandra Siroty, bez większych trudności można odnaleźć jego osobę ukrytą za plecami postaci fikcyjnych. Czytając opowiadanie Lubow Siroty pt. Prypecki syndrom, już od pierwszych akapitów trudno się oprzeć wrażeniu, że główni bohaterowie - Irina i Denis - są jedynie pretekstem do podjęcia przez autorkę wielu wątków biograficznych ${ }^{37}$. Pojawia się tu uniwersalne pytanie o wąską granicę pomiędzy dokumentem a fikcją, o czym w kontekście postpamięci również pisze Marianne $\mathrm{Hirsch}^{38}$.

Ukazany w scenariuszu moment ewakuacji miasta Prypeć, podczas której Denis obserwuje samoloty i wojskowych, nasuwa skojrzenie ze wspominaną przez Aleksandra zabawą w żołnierzy.

- Wow, wojna!! Extra! - krzyknąt Denis.

- Rat-tat-tat-tat.

Chtopcy zaczynaja strzelać ze swoich niewidzialnych karabinów maszynowych. Następnie zabawe przejęli chtopcy z drugiego autobusu.

- Denis! - Irina próbuje wptynać na syna, ale Oleg ją powstrzymuje.

- Pozwól mu się bawić. Nikt nie wie, co nas czeka ${ }^{39}$.

Ze słowami z opowiadania w podobny sposób koresponduje wspomnienie Aleksandra z obserwacji elektrowni z Mostu Śmierci ${ }^{40}$ : Dzisiaj byt subbotnik ${ }^{41}$. Zamiataliśmy podwórko szkolne. - Denis ktamie. Tak naprawdę po szkole poszedt nad rzekę, ale o tym Irina dowiedziata się dużo późniejar2.

Opowiadanie Lubow Siroty ukazuje, jak niewielka była wiedza mieszkańców na temat radioaktywności i jak bardzo nie zdawali sobie sprawy z zaistniałego zagrożenia. Autorka wspomina moment, gdy podczas ewakuacji z jednego z autobusów dobiegał radosny śpiew. Wraz z każdą stroną opowiadania wzrasta jednak niepokój, strach i potrzeba walki ze zdrowotnymi konsekwencjami, jakie pojawiły się tuż po wysiedleniu.

36 Wywiad swobodny kierowany z Aleksandrem Sirotą, przeprowadzony na drodze internetowej korespondencji, w okresie lipiec-czerwiec $2016 \mathrm{r}$.

37 M. Hirsch, Żatoba i postpamięć... Autorzy zwracają uwagę na tworzenie postpamięciowych narracji w wyniku wyobrażenia i kreacji przez „drugie pokolenie”. W przypadku Lubow i Aleksandra Sirotów twórczość jest nie tyle postpamięciowym przedmiotem badań, ile wpływa na kształtowanie postpamięci syna, która przekazywana jest dalej w postaci narracji przewodnickiej.

38 M. Hirsch, Żatoba i postpamięć...

39 L. Sirota, The Pripyat Syndrome. A Film Story, Washington 2013, s. 14.

40 Most nazwano później „Mostem Śmierci”, ponieważ po 26 kwietnia 1986 roku było to miejsce szczególnie radioaktywne (dawka niemalże śmiertelna - ok. 50 rentgenów promieniowania).

${ }^{41}$ Subbotnik (z ros. sobota) - dni przeznaczone na prace publiczne - sprzątanie ulic, zbieranie śmieci itd.

42 L. Sirota, The Pripyat Syndrome... 
Lubow Sirota, podobnie jak główna bohaterka Irina, zaangażowana była w życie kulturalne Prypeci. To właśnie Pałac Kultury „Energetyk” Aleksander wspomina z największym sentymentem. W swoim liście pisze: Patac Kultury byt dla mnie drugim domem, ponieważ moja mtoda, zdrowa i energiczna mama spędzata bardzo dużo czasu w pracy, wktadata wszystkie swoje sity $w$ życie kulturalne miasta. Dziś moja mama jest inwalidka i ma trudności ze zrobieniem zakupów $w^{43}$. I dalej: Moja mama zachorowata tuż po awarii. Lekarze mówia, że ma caty bukiet czarnobylskich przypadtości ${ }^{44}$.

Zakończenie opowiadania nie ma odzwierciedlenia w rzeczywistości, niemniej zasługuje na uwagę. W ostatniej scenie chłopiec wspomina matkę, wyjmując zdjęcie w ramce, które dostał od niej latem 1986 roku. Na fotografii widzi Irinę mtoda i uśmiechnięta, patrzaca z nadzieja na lepsza przysztość ${ }^{45}$. Kluczowe jest tu pytanie chłopca, które kieruje do współtowarzysza podróży w pociągu - o to, czy ten może dać mu chwilę na przypatrzenie się zdjęciu. Marianne Hirsch pisze: Konsekwentne uprawomocnienie tego, co dokumentalne sprawia, że fotografia archiwalna - obok mówionego świadectwa ocalonego - staje się szczególnie silnym medium, ze względu na swój bezpośredni związek ze źródtem ${ }^{46}$. Zdjęcia Prypeci to jedyny sposób, aby przenieść się wspomnieniami nie do umarłego miasta, ale do tego tętniącego życiem. W opisie zdjęcia Iriny zawarta została cała, wcześniej opowiedziana historia; niczym za dotknięciem magicznej różdżki, nagle słowa zdają się zbędne ${ }^{47}$.

Ze starych nagrań wideo oraz fotografii podczas konstruowania swej prypeckiej narracji korzysta dziś również Aleksander Sirota. Stosowana przez niego metoda, polegająca na analizie porównawczej wymarłej rzeczywistości prypeckiej z prezentacją zdjęć i filmów sprzed czarnobylskiej awarii, jest bardzo silnym środkiem przekazu. Roland Barthes w Świetle obrazu. Uwagi o fotografii pisze: Na tej ponurej pustyni nagle pojawia się przede mna zdjęcie: ożywia mnie i ja użyczam mu życia. Bo tak muszę nazwać site przyciagania, która sprawia, że zdjęcie istnieje: ożywianie $e^{48}$. Aleksander Sirota ożywia porzuconą przestrzeń poprzez nałożenie obrazu sprzed 30 lat. Jedna ze scen filmu dokumentalnego z udziałem Siroty pt. Lazurowy pyt ${ }^{49}$ nakręcona została w samochodzie. Dziennikarz wraz z Aleksandrem jadą wzdłuż wymarłej ul. Lenina - tuż przed katastrofą była to jedna z głównych ulic Prypeci. Dziś trudno się zorientować, w którym momencie się zaczyna. Odnosi się raczej wrażenie, jakby się jechato wzdtuż leśnej drogi - podkreśla narrator (Andrij Mostrenko). Nagle Aleksander podnosi tablet na

43 A. Sirota, I want them to remember...

44

45 L. Sirota, The Pripyat Syndrome..., s. 137.

J. Kristeva, The Dialectics of Unspeakability. Language, Silence and the Narraties of Desubjectification, „PMLA” 1987, nr 102, cyt. za: M. Hirsch, Żatoba i postpamięć... s. 257. Ta nowa retoryka apokaliptyczna znalazta swoją realizację $w$ dwóch skrajnościach, które choć wydają się przeciwieństwami, często się uzupetniają: nadmiar obrazów i wycofanie stów.

48 R. Barthes, Światto obrazu. Uwagi o fotografii, przeł. J. Trznadel, Warszawa 1996, s. 35.

49 Lazurowy Pyt (oryg. Аазуровий пил), reż. Вомодимир Рибась, 2016, [online] https://ok.ru/video/41840019974, 8 IX 2016. 
wprost siebie (znacznie przybliżając do przedniej szyby) i mówi: Oto ulica Lenina, która wtaśnie przejeżdżamy. Oto jak wygladata przed katastrofa. W tle słychać głos narratora filmu z lat 80. XX wieku, który opisuje Prypeć jako przykład nowoczesnego, komunistycznego miasta. Proroczo zaznacza, że jedne miasta znikają wraz z końcem wieku, w którym powstały, przeznaczeniem innych jest stanowić dom dla kolejnych pokoleń. $\mathrm{Na}$ ekranie widzimy ul. Lenina między pięknymi nowymi osiedlami, gdzie spacerują młodzi ludzie z dziećmi. Pomiędzy szeroką ulicą a chodnikami posadzone są młode drzewka i róże. Świeci słońce, mieszkańcy sprawiają wrażenie zadowolonych. Następnie kamera oddala się od filmu prezentowanego na urządeniu mobilnym, a wychodzi poza szybę samochodu, gdzie odbiorca styka się z ponurą rzeczywistością. Byli mieszkańcy Prypeci z nostalgią wspominają miasto, idealizując przeszłość, niemalże na wzór komunistycznej propagandy.

W podobny sposób Aleksander udziela wywiadu dziennikarzowi portalu internetowego Onet.p $\mathrm{l}^{50}$. W nagranym materiale Aleksander opowiada o szkole. Pokazuje pomieszczenie, w którym miał lekcje, swoją ławkę, a następnie przed budynkiem stawia urządzenie mobilne, na którym wyświetla się zdjęcie jego klasy, zrobione przed wejściem do szkoły. W podobny sposób wyciąga rękę z ekranem, na którym wyświetla się film ukazujący boisko, po którym biegają uśmiechnięci chłopcy: Ten chtopiec po lewej to $j a$. Za tabletem natomiast znajduje się przestrzeń porośnięta zielenią będąca miejscem prezentowanym przez Aleksandra.

Ukazany kontrast po raz kolejny pokazuje, jak wielką siłę wyrazu ma obraz przeszłości w zetknięciu z miejscem „zapomnianym”. Aleksander jednak w wywiadzie mówi: $U$ nas nie byto prawie żadnych naszych zdjęć z Prypeci. One pojawity sie już znacznie później. Kiedy zaczątem zajmować sie ta tematyka i wyszukiwać materiaty zdjęciowe i wideo. [...] To pamięć o mieście mtodości miata wptyw na to, że zostaty zebrane zdjęcia ifilmy, nie na odwrót. Nie potrzebuje czyjejś pamięci i obrazów - moich wtasnych mi wystarcza ${ }^{51}$. Słowa Aleksandra pozwalają spojrzeć na potrzebę gromadzenia zdjęć na Pripyat.com nie tyle jako chęć odbudowania lub uzupełnienia pamięci indywidualnej. Nadrzędnym celem jest tu przywrócenie pamięci miejscu, ożywienie go i nadanie wartości, a następnie przekazanie tej pamięci innym, w tym przypadku - turystom. Najczęściej goście zainteresowani sa nie wspomnieniami z ewakuacji, a żywym miastem oczami prypeckiego chtopca. [...] Staram się dać szansę zobaczyć żywe miasto, poczuć wydarzenia sprzed 30 lat. Odkryć ludzkie emocje, jeśli można tak powiedzieć. A resztę robi atmosfera tego miejsca ${ }^{52}$. Prezentowane przez Aleksandra fotografie, które nierzadko turysta może znaleźć również na stronie Pripyat.com, w sposób nieświadomy są przez nich rejestrowane. Marianna Michałowska nazywa to tzw. „mimowolną pamięcią”, która przekształca proces postrzegania $\mathrm{w}$ przeżycie ${ }^{53}$. Jednak na moment doświadczania miejsca za pośrednictwem fotografii składa się „zapomniana” wizja osoby robiącej zdjęcie oraz

\footnotetext{
M. Wyrwał, Po katastrofie...

Wywiad swobodny kierowany...

52 Tamże.

53 M. Michałowska, Obraz utajony. Szkice ofotografii i pamięci, Kraków 2007, s. 142, Biblioteka f5, t. 1.
} 
jej ożywienie i reinterpretacja poprzez „spojrzenie” kolejnych osób. Proces „przypominania" jednak nie jest stały. Janina Struk pisze: Przekonani, iż fotografie odzwierciedlaja rzeczywistość przesztości wkraczamy do królestwa fikcji ${ }^{54}$. Fotografie, podobnie jak pamięć, ulegają zmianie, w zależności od tego, do kogo należą. Obie mogą stanowić świadectwo chwili w czasie, ale moga też ukrywać historię, która leży poza obrazem ${ }^{55}$.

„Mimowolna pamięć” wśród turystów jest konstruowana za pośrednictwem narracji opartej na doświadczaniu miejsca poprzez stare fotografie kontrastujące $\mathrm{z}$ wizją apokalipsy. Mimo że we wspomnieniach przyjezdnych będzie dominowała historia dziesięcioletniego chłopca, bawiącego się żołnierzykami, to umiejscowiona ona zostanie w rzeczywistości zarejestrowanej przez inne osoby. Połączenie narracji Aleksandra $\mathrm{z}$ fotografiami byłych mieszkańców Prypeci oraz obrazami zrobionymi przez przyjezdnych tworzy nową opowieść. Doświadczenie turystyczne obudowane wizjami Aleksandra i pośrednio Lubow Siroty pozwala spojrzeć na katastrofę czarnobylską przez pryzmat mieszkanców Prypeci przeżywających traumę. Czarnobyl w oczach przyjezdnych zmienia swe oblicze. Niedostępna strefa, stanowiąca czarny punkt na mapie świata, zostaje oswojona, a w miejscu „niewidzialnego wroga” pojawia się człowiek, który chce przed nim przestrzec następne pokolenia.

Gdy Aleksander Sirota po raz pierwszy w 1994 roku powrócił do miasta dzieciństwa, czuł, że nie może żyć dalej, pozostawiając za sobą ruiny, pustkę i umarłe miasto ${ }^{56}$. Wiedział, że musi dzielić się swoją historią, aby świat zrozumiał, że do atomu trzeba dorosnaç ${ }^{57}$. „Horyzont oczekiwañ” ${ }^{\circ}$, jaki zakreśla dziś miasto Prypeć, jest szeroki i wyraźny. Na linii tej można dostrzec również turystę, który powraca do domu z bagażem doświadczeń i snuje opowieść o małym chłopcu, który nudził się w szkole, a do której później nie mógł już powrócić, mimo że bardzo tego pragnął.

\section{BIBLIOGRAFIA}

Aleksijewicz S., Czarnobylska modlitwa. Kronika przysztości, przeł. J. Czech, Wołowiec 2012, Reportaż - Wydawnictwo Czarne.

Banaszkiewicz M., Tanatoturystyka. Doświadczenie, pamięć, etyka, „Politeja” 2015, nr 3.

Barthes R., Światto obrazu. Uwagi o fotografii, przel. J. Trznadel, Warszawa 1996.

Cataluccio F.M., Czarnobyl, przel. P. Bravo, Wołowiec 2013, Sulina.

Hirsch M., The Generation of Postmemory, „Poetics Today” 2008, Vol. 29, nr 1, [online] https:// doi.org/10.1215/03335372-2007-019.

Hirsch M., Żałoba i postpamięć, [w:] Teoria wiedzy o przesztości na tle wspotczesnej humanistyki. Antologia, red. E. Domańska, Poznań 2010.

54 J. Struk, Holokaust w fotografiach. Interpretacje dowodów, Warszawa 2004, s. 280.

55 Tamże.

56 A. Sirota, I want them to remember...

57 M. Wyrwal, Po katastrofie...

58 R. Koselleck, „Przestrzeń doświadczenia”... 
Jaworowski Z., Czarnobyl, „Racjonalista” 2009, 10 IV, [online] http://www.racjonalista.pl/ kk.php/s.

Koselleck R., „Przestrzeń doświadczenia” $i$ "horyzont oczekiwañ” - dwie kategorie historyczne, [w:] R. Koselleck, Semantyka historyczna, oprac. H. Orłowski, Poznań 2012.

Macdonald S., Difficult Heritage. Negotiating the Nazi Past in Nuremberg and Beyond, London 2009.

Michałowska M., Obraz utajony. Szkice o fotografii i pamięci, Kraków 2007, Bibliotekaf5, t. 1.

Nora P., Między pamięcia a historią. Les lieux de mémoire, przel. W. Dłuski, „Tytuł Roboczy: Archiwum" 2009, nr 2.

Ricoeur P., Pamięć - zapomnienie - historia, [w:] Tożsamość w czasach zmiany. Rozmowy w Castel Gandolfo, red. K. Michalski, Kraków 1995, Demokracja - Znak.

Owsianowska S., Banaszkiewicz M., Trudne dziedzictwo a turystyka. O dysonansie dziedzictwa kulturowego, „Turystyka Lulturowa” 2015, nr 11.

Sawada A., Chaitin J., Bar-On D., Surviving Hiroshima and Nagasaki - Experiences and Psychosocial Meanings, „Psychiatry” 2004, Vol. 67, nr 1.

Tunbridge J.E., Ashworth G.J., Dissonant Heritage. The Management of the Past as a Resource in Conflict, Chichester 1996.

Saryusz-Wolska M., Spotkania czasu z miejscem. Studia o pamięci i miastach, Warszawa 2011, Communicare.

Sirota A., I want them to remember. A letter from a child of Chernobyl, „DHA News” 1995, nr 16. Sirota L., The Pripyat Syndrome. A Film Story, Washington 2013.

Struk J., Holokaust w fotografiach. Interpretacje dowodów, Warszawa 2004.

Zhukova E., From Ontological Security to Cultural Trauma: The Case of Chernobyl In Belarus and Ukraine, „Acta Sociologica” 2016, nr 59 (4).

\section{Strony internetowe}

http://news.tut.by/society/486540.html.

https://www.rt.com/news/chernobyl-tourist-no-go-zone-397.

http://www.racjonalista.pl/kk.php/s.

http://culture.pl/pl/tworca/maciek-nabrdalik\#dziela.

http://wiadomosci.onet.pl/tylko-w-onecie/po-katastrofie-w-czarnobylu-wyjechal-na-cale-

-zycie-powrot-jest-bolesny/t0lzxs.

http://www.pripyat.com.

https://ok.ru/video/41840019974.

Anna DUDA - absolwentka kulturoznawstwa międzynarodowego oraz zarządzania kulturą na Uniwersytecie Jagiellońskim w Krakowie. Obecnie studentka Wydziałowych Kulturoznawczych Studiów Doktoranckich tegoż. Interesuje się zagadnieniami z obszaru antropologii turystyki. 